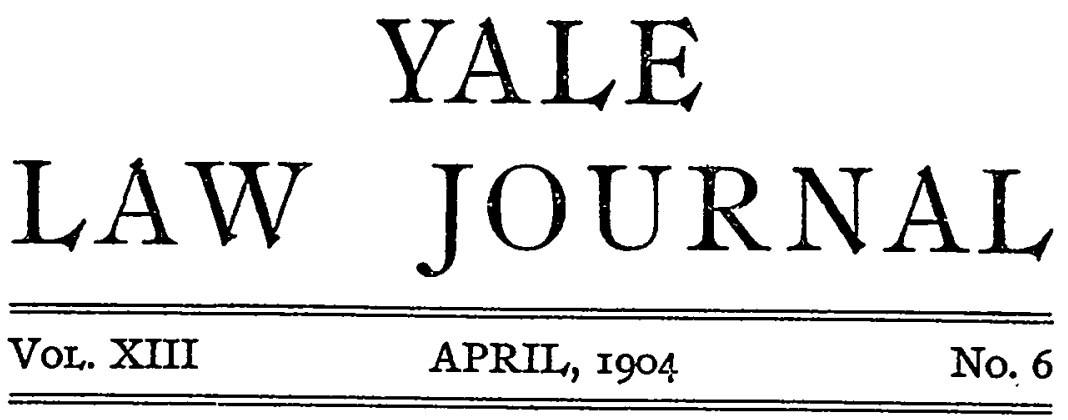

\title{
STATUTORY ESTATES IN PLACE OF AN ESTATE TAIL.
}

Mr. Zane in a recent article ${ }^{x}$ on Determinable Fees gave some space to the problem of the character and validity of limitations arising by statute upon the creation of an estate tail. Believing that he by no means exhausted the possibilities of this branch of his larger subject, I have ventured upon it in the hope of adding somthing while his article is still fresh in the minds of readers.

I.

STATUTES.

There are to-day in Arkansas, Colorado, Missouri and Vermont statutes concerning estates tail, in every respect material to the present inquiry, identical with section 6 of the Illinois Act on Conveyances." This last is as follows: "In cases where, by the common law, ${ }^{3}$ any person or persons might hereafter become seized, in fee tail, of any lands, tenements or hereditaments, by virtue of any devise, gift, grant or other conveyance, hereafter to be made, or by any other means whatsoever, such person or persons, instead of being or becoming seized thereof in fee tail, shall be deemed and adjudged to be, and become seized thereof, for his or her natural life only, and the remainder shall pass in fee simple absolute, to the person or persons whom the estate tail would, on the death of the first grantee, devise, donee in tail, first pass, according to the course of the common law, by virtue of such devise, gift, grant or conveyance." 
Of these the Missouri Act of $1825^{4}$ seems to have been the first. It remained in force in Missouri until 1845, when it was so altered" as to read that "upon the death of such grantee or devisee [in tail], the said lands and tenements shall go and be vested in the children of such grantee or devisee, equally to be divided between them, as tenants in common in fee; but if there be only one child, then to that one in fee; and if any child be dead, the part which would have come to him or her, shall go to his or her issue, and if there be no issue, then to his or her heirs." In 1866, ${ }^{7}$ however, the Missouri Legislature restored the Act of I825 to the statute book. In 1827,8 Illinois copied ${ }^{\circ}$ the Missouri Act of 1825 and this law has remained without change in force in that state. ${ }^{10}$ In Arkansas the statute appeared first in $1837:^{11}$ in Vermont in $1840 ;^{12}$ and in Colorado in $1867 .^{13}$ In these three states the statute has remined in force since its first passage in its present form. ${ }^{14}$

Suppose then real estate be limited, in a state where such a statute is in force, to $A$ and the heirs of his body, remainder to $B$ and his heirs. Two groups of problems arise: one with respect to the statutory remainder; the other as to the remainder expressly limited after the estate tail.

II.

THE STATUTORY REMAINDER.

Uncertainty and conflict among the authorities suggests inquiry upon the following points respecting the statutory remainder: Ist. Is is vested or contingent? 2nd. If it be held to vest in a child of the donee in tail as soon as such child is born, is it subject to be divested if the child die before the death of the donee?

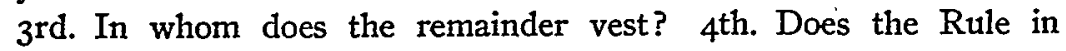
Shelley's case apply to it?

I. It is agreed that so long as there is no issue of the body of the donee in tail the statutory remainder is contingent. ${ }^{15}$ The difficulty arises where issue have been born. Do they take a vested remainder or one contingent upon their surviving the donee and being his heir?

There would seem to be a very obvious difficulty with holding the remainder in fee to the heirs of the body of the donee in tail a vested remainder at any time prior to the death of the donee in tail. The statute expressly limits the remainder in fee to the "person or persons whom the estate tail would, on the death 
of the first grantee, devisee donee in tail, first pass, according to the course of the common law, by virtue of such devise, gift, grant or conveyance." Now at common law it was impossible to ascertain to whom the estate would pass until the death of the donee in tail, since by the course of the common law the estate tail at that time passed regularly by descent to the first tenant in tail's heir at law provided such heir at law was of the issue of the body of the tenant in tail. ${ }^{16}$ The remainder then was clearly subject to a condition precedent and the conditional element was incorporated into the description of the remainder-man. ${ }^{17}$ The case under the English authorities would be one of the typical examples of a contingent remainder. ${ }^{18}$

The Illinois Supreme Court seems at present to incline strongly toward the doctrine that the remainder is vested ${ }^{10}$ upon the ground that a remainder is vested at any time if there is, "at that time, a person ready and entitled to take possession as remainder-man, should the particular estate then determine, although, should the particular estate determine at some other time, such person might not be entitled to the remainder."20

With regard to the Missouri cases it is important to observe that where the conveyance involved was governed by the law as it stood from 1845 to 1866 results might properly be reached which were of very doubtful propriety under the Missouri statute in force from I825 to I845 and again from I866 to the present time. Mr. Zane seems to have overlooked this, for he states the Missouri law under the definition of a vested remainder suggested above the issue as soon as any issue comes into being." In support of this he cites Garth v. Arnold, ${ }^{21}$ a case where the conveyance was controlled by the law as it stood in I855. In this view the case is perfectly sound, for the statute in force at that time expressly provided that the remainder "shall go and be vested in the children of such grantee, or devisee, equally to be divided between them, as tenants in common in fee." Curiously enough Mr. Zane's oversight did not altogether mislead his readers as to the actual state of the law in Missouri, for it had been held in Frame v. Humphreys ${ }^{22}$ that the remainder vested as soon as any child was born to the donee, the Missouri Court apparently adopting the same definition of a vested remainder which obtains in Illinois.

2. Even the hypothesis that the statutory remainder is vested under the definition of a vested remainder suggested above, it is clear that upon principle it should be subject to 
a condition subsequent, so that should the remainder-man die before the death of the donee in tail his vested remainder would be divested in favor of such person as should actually answer the description of heirs of the body of the donee in tail at the donee's death. If this be not so-if the remainder be not only vested but indefeasible, then, instead of a gift to "the person or persons whom the estate tail would, on the death of the first grantee, devisee donee in tail, first pass, according to the course of the common law," there will be in reality a remainder to the "children" of the donee.

In Missouri and Illinois where there is a tendency to hold the remainder vested, there is also an inclination to hold it indefeasible. But the authorities in each state are not altogether harmonious upon the point.

In Illinois there is an interesting alternation of dicta in favor of divesting the remainder and decision against it. In Butler v. Hues$t_{i s^{23}}$ the Court said "Mrs. Huestis [the donee in tail] under our statute, would take a life estate in the property and the remainder would pass in fee simple absolute to her children, although it might open to let in after born children, and be divested as to such as should die before the determination of the life estate." Yet in Voris $v$. Sloan, ${ }^{24}$ the preceding case in the same volume of reports, the Court actually held the remainder indefeasible by declaring it error in a decree not to recognize that upon the death of two children of the donee without issue surviving, the children's share descended to their mother, the donee in tail, as well as to the other children. Still later, in Lehndorf $v$. Cope, ${ }^{25}$ we have a clear cut dictum of Mr. Justice Shope that the remainder though vested is subject to be divested. Speaking of this statutory remainder he says: "The person to whom the remainder is limited is ascertained, the event upon which it is to take effect is certain to happen, and although it may be defeated by the death of such person before the determination of the particular estate, it is a vested remainder." However, subsequently in Welliver v. Jones ${ }^{26}$ the Court again held squarely that the remainder was not subject to be divested so that when the sole lineal heir of the donee dies without leaving issue in the life of the donee the remainder passed by descent to her collateral heirs, viz. her mother the donee, and half brothers and sisters who were children of the donee's husband's first wife. Still later, in Kyner v. Boll, ${ }^{2 \tau}$ there is an express recognition of the 
propriety of the result reached in Voris $\pi$ Sloan and Welliver $v$. Jones. Thus the direct authorities in Illinois stand.

There is another line of cases however, which indirectly indicates that the Illinois Supreme Court has not unqualifiedly given itself over to the idea that the statutory remainder is in terms to the "children" of the donee. Where the limitations are to A for life, remainder to the heirs of the body of $A$, it has been continuously asserted that the rule in Shelley's case had no application, ${ }^{28}$ until, in two quite recent cases, ${ }^{20}$ the application of the rule is not even considered. Now the only ground for saying that the Rule in Shelley's case does not apply here is that if it did A would take a life estate with a remainder in tail to $A$, which by the doctrine of merger would give $A$ an etsate tail and this by the statute on entails would be turned back into the estates as they were originally created, viz., a life estate to $A$ with a contingent remainder in fee to his lineal heirs. $^{30}$ It is apparent enough then that if by the statute on entails the statutory remainder runs to the "children" so that they have not only a vested, but an indefeasible interest as soon as born, there is no reason why the Rule in Shelley's case should not be applied.

In this state of the Illinois authorities Mr. Zane's statement of the Illinois law is open to some objections: First, he undertakes to say quite positively what the law is. Second, judged by what seems to be a clear preponderence of direct'authority he states it incorrectly. He says, "If the issue dies in the lifetime of the first taker, its share descends only to its issue, and not to the heir general of the deceased child, and if it dies without issue during the lifetime of the first taker, that particular issue is eliminated, and at the death of the donee in tail the issue then living take the remainder in fee." If the view that the remainder is not only vested but indefeasible and the actual result of Voris $v$. Sloan and Welliver v. Jones are to prevail, then this statement is incorrect, since it was the distinct result of that view and the holding of those cases that upon the death of a child of the donee in the donee's lifetime without issue, the child's vested remainder descended to its collateral heirs. Third, Mr. Zane has failed to perceive that his own statement would be perfectly correct if the view prevailed that the statutory remainder, though vested, was subject to be divested. On this hypothesis, if the donee's child is dead with issue at the death of the donee, and those take the remainder who are the donee's lineal heirs by the statute on descent, then by that statute 
the issue of a deceased child stands in such deceased child's place ${ }^{31}$ and take as lineal heirs-not of the child, but of the donee. If on the other hand the child of the donee dies without issue then the other children take the remainder as the lineal heirs of the donee. Mr. Zane's own explanation of the significance of the results contained in his statement is quite different. "It thus appears," he says, "that during the lifetime of the donee the remainder to the issue is treated as an estate tail; it becomes a fee simple upon the death of the donee in tail. If no issue survive the donee, the other remainder in fee takes effect. It thus appears that there is one species of estate tail upon which the statute has no effect." From this he would appear to believe that the statutory remainder is sometimes subject to be divested and sometimes not-that if the donee's child dies leaving issue the vested remainder of the child becomes indefeasible and then there is a descent to the issue of the child, while if the child die leaving no issue the remainder is subject to be divested in favor of the other children. This, it is submitted, states the law worse than it really is. It adds to a subject already unnecessarily overloaded with artificial and complex distinctions, a refinement which finds no support in the language of the statute upon which it must be supposed to rest.

The Missouri cases must be examined with special care, for if the case be governed by the law as it stood there from $I 845$ to $I 866$ the statutory remainder is not only vested but it is either not subject to be divested at all and so may pass by descent to the heirs general of the child of the donee, or, if subject to be divested, it is in the manner pointed out by the statute, i.e., in favor of the issue of a deceased child of the donee, or if there be none, then in favor of the collateral heirs of such child. Mr. Zane's failure to observe this has caused him to state the law under the Missouri statutes in force from 1845 to $I 866$ as if it were the law of Missouri under the statute similar to the one quoted at the beginning of this article, which was in force from 1825 to 1845 and from 1866 to the present time. He cites Garth v. Arnold ${ }^{32}$ decided with reference to the Missouri Act of 1845 (referred to in the case as in R. S. 1855) and from it states the law generally for Missouri to be that, "if a child dies without issue before the first taker, the vested remainder is not thereby divested, but the heirs of the deceased child take." Again, however, Mr. Zane did not entirely mislead his readers as to the actual state of the law under the present statute, for in Frame v. Humphreys ${ }^{38}$ the Missouri Court seems 
squarely to have held that the remainder could not be divested in such a case. It is difficult, nevertheless, to regard the Missouri law as settled this way until the earlier case of Rozier v. Graham, $^{38}$ where, if the remainder was not actually held contingent, it was at least held subject to be divested, be expressly overruled.

3. In whom does the remainder vest? This involves two other questions: (a) Is the remainder in those who are the lineal heirs of the donee according to Blackstone's canons or according to modern statutes of Descent? (b) Assuming that lineal heirs under the modern statute take the remainder, can you restrict them to a special class in the case of an estate tail special?

(a) In Arkansas, ${ }^{35}$ Illinois, ${ }^{36}$ and Vermont ${ }^{37}$ it seems clear that the remainder under the statute vests in such issue of the donee in tail as are his heirs under the statute on descent. In all the cases the point is assumed, no other view being suggested. It is hard to say that this is not a proper result, and yet there are difficulties with it. The holding is preciesely one of those which the Court ought to have justified when it was pronounced to be the law so as to put forever at rest doubts based upon very plausible reasoning. According to the language of the statute the remainder in fee is limited "to the person or persons whom the estate tail would, on the death of the first grantee, devisee donee in tail, first pass, according to the course of the common law." It is perfectly clear that the descent if traced literally "according to the course of the common law," must have followed such of Blackstone's canons ${ }^{38}$ as are applicable to lineal descent. (2) The male issue shall be admitted before the female. (3) Where there are two or more males in equal degree, the eldest only shall inherit, but the females altogether. (4) The lineal descendants, in infinitum, of any person deceased shall represent their ancestor: that is, shall stand in the same place as the person himself would have done had he been living. Thus, the eldest son alone, if there were one, would take the remainder in fee, and the rule of primo-geniture would have survived to the present day in this one case. Such a conclusion is not so impossible as it might at first sight seem. It was in fact adopted in two Missouri cases. ${ }^{38}$ In the more recent one the Court said: "That under this statute, by the grant in the deed, to Mary A. Walker and the heirs of her body, she took only a life estate, is beyond dispute. The serious question is, to whom did the other part, the remainder in fee simple absolute, go? The answer of the statute is, to the persons to whom the 
estate tail would on her death first pass according to the common law, by virtue of the grant. This grant being of a fee tail general, according to the common law, its course by that law is similar, so far as it goes, to that of an estate in fee simple (Williams, R. P. I20, I7 Int. Ed.), and as at the date of the grant there were living sons and daughters of the said Mary A. Walker, of whom John D. Walker was the eldest, and as to him the estate tail would first pass on the death of his mother according to the common law (I Cooley's Black., 4 Ed. bottom pp. 605 and 606), to him the remainder in fee simple absolute passed under the statute by virtue of the grant, ***."40

There would seem to be only two possible grounds for reaching a different result: First, that a modern statute changing the common law mode of descent had, prior to the statute on entailments, altered the course of descent in cases of estate tail and that the act concerning entails in referring to "the course of the common law" really referred to the common law as modified by the modern statute. Second, that a statute of descent passed subsequent to the act regarding entails by implication modified it so that "according to the course of the common law" must be read "according to the statute of descent."

An examination of the statutory history of Illinois will show how difficult it is, in that state at least, to sustain the results of the cases there, upon either of the grounds suggested.

At the time the Act of 1827 concerning entails was passed, there had been in force in Illinois as a territory and as a state since 1787 a statute changing the common law course of lineal descent so that children and descendants of a deceased child shared in equal parts, the descendants of a deceased child or grandchild taking the share of their deceased parent in equal parts among them.11 Did these acts change the course of descent in the case of an estate tail? And if so did the act of 1827 refer to the course of descent as changed by them?

It is clear that the first statutes of descent were not in terms confined in their application to estates in fee simple, for they begin: "That the estates of both resident and non-resident proprietors * * dying intestate shall descend." "Proprietors" is a word which might well have included holders of an estate tail. An examination, however, of some early cases in Massachusetts, ${ }^{42}$ Pennsylvania,43 and Maine 44 will seem to indicate a strong tendency to hold that the modern statutes concerning descent, even when they 
are not in terms confined to estates in fee simple, ${ }^{45}$ do not apply to estates tail so that the descent there still continues to be to the eldest son, etc., according to the course of the common law. ${ }^{48}$ But from a careful examination of these cases it will appear that the results reached were influenced by a long period of recognition of estates tail and their descent according to the common law $^{47}$ and a consequent disinclination to overrule by implication merely a settled rule of property. ${ }^{48}$ It may fairly be assumed, however, that such considerations never could have influenced the Courts of Illinois and would not now do so. We may therefore assume for the purpose of the present discussion that the Supreme Court of that State would hold that the statutes of descent in force prior to 1827 did. apply to alter the course of descent of estates tail.40

Then we reach this question: Does the Act of 1827 in declaring that the remainder shall pass "to the person or persons whom the estate tail would, on the death of the first grantee, devisee donee in tail, first pass, according to the course of the common law" mean the common law as altered by previous statutes then in force? It seems pretty hard to answer this question in the affirmative. The common law and the statutory rules concerning descent were radically different. The latter did away with the former and superceded them. When therefore a new act was passed which referred in terms to descent "according to the course of the common law" the common law course of descent would seem to have been unequivocally distinguished and pointed out, and not a wholly different statutory mode. ${ }^{30}$ This was the position taken by the Missouri Court in the recent case of Frame v. Humphreys. There the Court said: "Although the common law of descents was never in force in this jurisdiction (Terr. Laws of Louisiana, r807 Cap. 39; Terr. Laws of Mo. 1815 Cap. I43; R. S. I825, p. 326; R. S. 1835, p. 222) that law was, as we have seen, preserved in the statute of conveyances, not as a law of descent, but to the extent only and for the single purpose of affording a rule for the delimitation of an estate tail created by grant or devise * * *."'s1

It is difficult to say that the statute of $1829,{ }^{62}$ concerning descents operated in any way to alter the language of the Act of 1827 concerning entails. If it did so it must be by implication merely. But there is no ground for any such implication since the Act of 1827 deals completely with the subject of entails and the subsequent statute concerning descent does not in terms, nor indeed need it be regarded as in the slightest degree inconsistent with the 
Act of I827. Subsequent events repel any inference that these two acts are at all inconsistent with each other, since they have been re-enacted in their original form in the subsequent revisions of $1845^{.53}$ and $1874^{.54}$

(b) Suppose, however, the general view to obtain that lineal heirs of the donee under modern statutes on descent take the remainder in fee. Then take this case: To $A$ and the heirs of his body by his present wife B. A has had a former wife and dies leaving children by both wives who are his heirs under the statute on descent. It is held in Illinois at least that in such a case only the lineal heirs of the donee by the particular wife will take. ${ }^{.5}$ And it seems to make no difference whether the Court regards the remainder as contingent or as vested subject to be divested, ${ }^{86}$ or vested and indefeasible. ${ }^{57}$ So if the limitation be to $A$ and the heirs male of his body, I suppose the remainder would be only to those of A's heirs under the statute on descent as are males.

This result ought to be questioned if for no other reason to show what liberties have been taken with this statute on entails. By it the remainder is created in those to whom the estate tail would on the death of the donee "first pass according to the course of the common law." Now if you construe this to mean "according to the course of the statute on descent," how can you support the remainder in the restricted class of the donee's lineal heirs by a particular wife? It is of no use to argue that the donor intended the class to be limited, for the statute completely frustrates the intention of the donor. It places statutory estates in place of the estate limited and if the statute says that the remainder shall be in those who are the donee's lineal heirs at the time of his death according to the statute on descent, what is to be done but to allow all the donee's lineal heirs to take? An excellent example of this exact mode of handling the statute is to be found in some New Jersey cases. A New Jersey statue of 1820,58 in terms created a remainder in the "children" of the donee.50 It is clearly the law under this statute that if an estate tail be limited to $A$ and the heirs of his body by a particular wife $B$, and he have no children by $B$, but does have children by another and different wife, the issue of such different wife will take the remainder in fee, because the statute says "children" without distinguishing between special classes of children. ${ }^{00}$ The Illinois cases which, while giving a remainder to those who may be heirs of the donee according to the statute on descent, restrict the class of such heirs as the donee has 
indicated simply point out the extreme liberty which a court may take with the language of a statute.

4. If the statute on entails be held to create in effect a remainder to the "children" of the donee which vests in each child indefeasibly as soon as born, then of course the Rule in Shelley's case can have no application. ${ }^{61}$ If the statute turns the estate tail into a life estate in A with a remainder in fee to those who at A's death would be his heirs at law either according to the statute on descent or according to the course of the common law, and if the remainder under such circumstances be regarded as one to which the Rule in Shelley's case applies, yet by the operation of that rule and the doctrine of merger A would have an estate tail again. The effect then of applying the Rule in Shelley's case would be to nullify the effect of the statute. It is properly enough held therefore upon this ground, if on no other, that the statutory limitations resulting from the creation of an estate tail cannot be subject to the operation of the Rule in Shelley's case. ${ }^{62}$

\section{III.}

THE REMAINDER AFTER THE ESTATE TAIL.

The remainder after an estate tail was vested and valid. ${ }^{.3}$ What then is the effect of the statutory estates upon this remainder? This question must be looked at with reference to three cases: IstWhere there never has been any issue of the donee in tail to take the statutory remainder; 2nd-Where, after the estate tail and remainder are created, children are born to the donee; $3^{\text {rd }}$-Where at the time the estates are created the donee in tail has children or other issue. In respect to each of these three cases the question must be asked upon two inconsistent hypotheses-that the gift after the estate tail is upon a definite failure of issue and that it is upon an indefinite failure of issue. Finally, it must be considered whether the ultimate interest is upon a definite or indefinite failure of issue.

I. If at the time the estate tail is created no issue of the donee are in existence the statutory remainder is contingent. If the ultimate interest is to take effect upon a definite failure of issue it will, upon the ground that the conditional element is incorporated with the gift to the remainder-man, ${ }^{64}$ be a contingent remainder and the case will be one of contingent remainders in fee in double aspect. If the ultimate interest is to take effect upon an indefinite failure of issue, it must do so as a shifting executory interest. However. in the recent case of Chapin 7 . Nott $t^{65}$ the ultimate interest was held 
to be a vested remainder. ${ }^{.6}$ This result was obtained by the application of the New York statutory definition of a vested remainder. ${ }^{B r}$

Is the ultimate future interest valid? It was clearly assumed and held to be so in Chapin $v$. Nott. If it be regarded as a real vested remainder so that the rule against perpetuities can have no application there is no doubt about its validity. If the ultimate interest be regarded as a contingent remainder upon a definite failure of issue it is not too remote. It is submitted also that it is valid as a contingent remainder on a definite failure of issue even though the ultimate gift be looked upon as limited to take effect on an indefinite failure of issue. It is clear that in the gift on an indefinite failure of issue there is included in effect a gift on a definite failure of issue if it occur. It is clear also that upon the definite failure of issue the ultimate interest takes effect as a contingent remainder, while upon the indefinite failure of issue it must take effect as a shifting executory interest. Under these circumstances the ultimate gifts upon the two different contingencies may be separated by operation of law, so that the ultimate gift will read as if it had been expressly limited to take effect "if the donee dies without issue him surviving or without issue in any generation." ${ }^{88}$ The shifting executory interest upon the latter contingency is clearly void for remoteness. The contingent remainder upon the former contingency is clearly valid.

2. Suppose now that after the estate tail is created the donee's first child is born.

If in accordance with the proper definition of a contingent remainder the statutory remainder was still contingent after the birth of the donee's first child, then by the same definition of a contingent remainder the ultimate interest, if upon a definite failure of issue, would be a contingent remainder and both remainders would take effect as contingent remainders in double aspect. If the ultimate interest were upon an indefinite failure of issue then it would be a shifting executory interest after a contingent remainder in fee and clearly too remote; but the contingent remainder in fee on a definite failure of issue contained in it and separable from it would be valid enough.

If, however, upon the peculiar definition of a vested remainder toward which the Illinois Court has inclined the interest after the estate tail be held a vested remainder before the birth of issue to the donee, then by the same definition the issue of the donee upon birth take a vested remainder. What then happens to the remainder 
of the ultimate taker which was also vested? Certainly it must lose its character as a vested future interest. You can hardly turn it into a contingent remainder even if it be upon a definite failure of issue because a contingent remainder after a vested remainder in fee is impossible. It must then take effect if at all as a shifting executory interest cutting short the vested remainder in fee to the donee's issue. But this again is contrary to the settled principle governing future interests that you cannot by events occurring subsequently to the creation of a contingent remainder turn it into an executory interest. ${ }^{69}$ Upon what principle then can you turn a vested remainder in fee into a shifting exectutory interest? Will you say that the remainder after an estate tail was always destructible and that by the necessary operation of recognized princioles of future interests it is destroyed the moment the remainder in fee vests in a child of the donee? Or will you attempt the introduction of some innovation in the law of future interests in order to support the interest after the estate tail so far as the rule against perpetuities will permit? Will you say that before the donee has issue the utlimate remainder-man has both a vested remainder in fee subject to be divested and a shifting executory interest in fee? Or shall a new rule of future interests be advanced, founded upon the modern endeavor of courts in all cases to give effect to the intention of the grantor or devisor, that any kind of a future interest may be turned into any other kind at any time by any event if necessary in order to carry out the intent of the creator of the interests? It is not at all clear that the ultimate interest, vested as a remainder before the birth of issue to the donee may not be wholly destroyed by the mere birth of issue apart from any question of remoteness, and quite regardless of whether the ultimate interest is on a definite or indefinite failure of issue.

If means be found to hold the intended interest after the statutory vested remainder in fee valid apart from the rule against remoteness, such future interest must necessarily take effect if at all as a shifting executory interest after a vested remainder in fee. If it were upon a definite failure of issue it would be unobjectionable from the point of view of remoteness. If created by will it would be an unobjectionable executory devise. If created in a deed it would be void in Illinois under Palmer $v$. Cook. ${ }^{70}$ If the ultimate interest is to take effect upon an indefinite failure of issue it cannot be void for remoteness. It must take effect also in any event as a shifting executory interest so there can be no ground 
for separating the ultimate interest into one upon a definite and the other upon an inclefinite failure of issue.

3. Suppose now that at the time when the estate tail and remainder over are created the donee in tail has children.

If you adopt the view that the donee's children take a contingent remainder, then the observations supra, respecting the case where the donee has children born after the creation of the estates and where the remainder to those children is regarded as contingent, apply.

If you adopt the view that the children take at once a vested remainder in fee, then the remainder after the estate tail can only take effect as a shifting executory interest. If it be upon an indefinite failure of issue it must be void for remoteness and there is no ground for separating the contingencies. If it be upon a definite failure of issue it will be unobjectionable on the ground of remoteness, but if created in a deed it must be void in Illinois under Palmer v. Cook.11 If created in a will it will be an unobjectionable shifting executory devise.

The recent case of Metzen $v$. Schop $p^{72}$ clearly sustains this last. There the testator devised to his wife for life with a remainder to his son, John Peter, in tail, and "in case of the death of my son, John Peter Metzen, without leaving issue and after the death of my wife" the property to be sold and the proceeds divided. It was held that the son did not get a fee simple, but only a statutory life estate with a statutory remainder in fee "to the heirs of his body." That was all that was involved, but the Court evidently, to forestall further litigation, went out of its way to say that the interest after the estate tail was limited upon a definite failure of issue, and intimated that it was a perfectly valid devise. The use of the word "leaving" in the phrase "without leaving issue" made it, upon the English cases respecting personalty" and the Illinois cases regarding realty as well, ${ }^{74}$ a gift on a definite failure of issue. Then it appears that the son, John Peter, was married and had issue before the testator died, which issue may fairly be assumed to have been living at the testator's death. If then that child took a vested statutory remainder in fee upon the death of the testator the gift over upon trust to convert was a valid executory devise upon a definite failure of issue when the testator died.

4. Up to this point questions raised respecting the remainder after the estate tail have been considered upon two hypothesesthat the ultimate interest was on a definite failure of issue and that 
it was on an indefinite failure of issue. It is apparent that the results reached will in certain cases be different according as one interpretation or the other is adopted. It is proper, therefore, that some consideration should be given to this problem of construction.

Suppose estates be limited to $A$ for life and if $A$ die without issue then to $B$ in fee. $A$ in that case takes an estate tail by a rule of construction founded on the assumption that B's estate is upon an indefinite failure in the issue of $\mathrm{A.}^{75}$ There would seem to be a palpable absurdity in holding, in such a case, that B's interest after the statutory estates into which the estate tail in $A$ is turned takes effect upon a definite failure of issue. If in a given jurisdiction there is in force a statute which declares that dying without issue means primarily a definite failure of issue, then if that applies the life estate in A cannot be turned into an estate tail. If it does not apply it must be because by the context of the instrument it is expressly indicated that an indefinite failure of issue is meant. The life estate must then be enlarged into a fee tail and the interest after it becomes one upon an indefinite failure of issue. In Nott \%. Fitzgibbon ${ }^{76}$ the Court seems to have performed the curious process of holding that the rule which enlarged the life estate into a fee and the statute which required "dying without issue" to mean a definite failure of isste could both be applied to the same limitations.

Suppose the estates to be limited to $A$ and the heirs of his body and "in the event that the said A dies without issue" then to B and his heirs. This was the form of the gift in Chapin $\%$. Nott." "In the event that A dies without issue," while not the most artistic formula for limiting a remainder after an estate tail, ${ }^{78}$ was fully effective for that purpose. Whatever difficulties may have arisen in respect to this phrase in other cases there can be no doubt that when used to limit a further interest after an estate tail it referred to an indefinite failure of issue. So clearly was this in accordance with the real intent of the grantor or devisor that when the Wills Act $^{79}$ provided that the words "die without issue" should be construed to mean a want or failuure of issue in the lieftime or at the death of the person referred to and not an indefinite failure of issue, it added this proviso among others: "unless a contrary intention shall appear by the will by reason of such person having a prior estate tail." So strong is the inference from the context that the limitation to $B$ is expressed to be upon an indefinite failure of issue that even if such a statute contained only the general exception 
"unless a contrary contention shall appear," it might be held that an indefinite failure of issue was meant. How then can the creation of statutory estates in place of an estate tail alter that expressed intent? The ultimate interest must still remain a gift over on an indefinite failure of issue.

Grout v. Townsend ${ }^{80}$ so far from holding the contrary, as Mr. Zane evidently intends us to believe, seems rather to sustain this view. The Court of Errors ${ }^{81}$ did say that even if the donee in tail took a fee under the statue, which was originally subject to be defeated by her dying without issue surviving at her death, yet it was none the less alienable and the donee, having died leaving issue, it never could be divested. Then it went on to say very pointedly that the limitation over was void because to take effect upon an indefinite failure of issue: 82 "In determining that she [the donee] took an estate in fee simple by force of the statute abolishing entails, it follows of course that remainders limited to take effect upon the failure of issue in tail are void."

Statutes regarding entails of the sort dealt with have brought up problems in the law of future interests in courts where the casual character of the case has furnished but little incentive to either judges or counsel to exercise that degree of learning demanded in their solution. The result has naturally been the growth of a group of premises from which the precise and certain deductions to which the subject particularly lends itself are almost impossible. If all the consequences of the statute had been perceived from the first it is submitted that courts would more readily have reached the conclusion that the statutory remainder was contingent to "the person or persons whom the estate tail would, on the death of the first grantee, devisee donee in tail, first pass, according to the course of the common law;" that the interest after the estate tail took effect as a valid contingent remainder on a definite failure of issue in the donee, if the contingency was so expressed; that even if the ultimate interest was expressly declared to be upon an indefinite failure of issue yet the gift on a definite failure of issue which it included could still have been given effect as a valid contingent remainder if the estates limited were legal and not equitable.

Albert Martin Kales.

Northwestern University, Law School, Chicago. 


\section{APPENDIX.}

'I7 Harvard Law Review, 297.

"R. S. 1874 Ch. 30, Sec. 6. Hurd's R. S. (1899) Ch. 30, Sec. 6.

${ }^{3}$ The present Missouri Statute (R. S. I899, Vol. I, Par. 4592) reads, "where by the Common or Statute law of England any person might become seized in fee tail, ** * " so that it may be regarded as clearly referring to estates tail created by the statute de donis of Edward I. The same construction is put upon the language of the Illinois Statute: "The General Assembly must have intended to refer to estates tail created by the statute de donis. They speak of persons becoming seized of such estates by the common law, when we have seen that estates tail grew out of the statute de donis, and not out of the common law. * * * If, as is contended by the defendants in error, the General Assembly intended to restore the common law as it stood before the adoption of the statute de donis, they would simply have repealed that statute, and left the donee with power, on the birth of issue, to alien the estate, and re-purchase, and thus cut off both the remainder and reversion." Per Walker, C. J., in Frazer v. Board of Supervisors, 74 III. 282 , at pages $287,288$.

'R. S. 1825, Act concerning conveyances, Sec. 4; R. S. 1835, Act regulating conveyances, Sec. 5 .

${ }^{5} \mathrm{R}$. S. 1845, Act on conveyances, Sec. 5; R. S. 1855, Ch. 22, Sec. 5.

'Observe that the New Jersey Act of June 13th, 1820 (Rev. Stat. I82r, page 774 , Sec. 2), was in substantially this form, giving the remainder in fee to "children" of the donee. It seems to have continued in force in New Jersey down to the present time. (Elmer's Digest, p. 130, Sec. 6; Stat. of N. J. I874, p. 34I, Sec II ; Nixon's Digest 1709-1855, p. I96, Sec. II; Gen'l Stats. of N. J. I709-I895, Vol. 2, p. II95, Sec. II). Mr. Zane would seem to have overlooked this in including (I7 Harvard Law Review, 305, note 8) New Jersey in his list of States which have statutes regarding estates tail like that in force in Illinois and other States mentioned at the beginning of this article.

'R. S. 1866, Ch. 108, Sec. 4; Wagner's Mo. Stat. I870, p. 1351, par. 4; R. S. I879, p. 675, par. 394I ; R. S. I899, Vol. I, par. 4592.

'L. I827, p. 95 ; I A. \& D. R. E. S., p. 75.

'It would seem as if the Illinois Statute of 1827 must have been copied from the Missouri Act of 1825 . The two are absolutely identical in language, except that the Illinois Act has omitted six words which in the Missouri Statute make it apply to all estates tail created and existing at the time when the act went into effect.

${ }^{10}$ R. S. 1845, p. $104 ;$ R. S. 1874, p. 273.

${ }^{2 R}$ S. 1837, p. 189 , Ch. 3I, Sec. 5 .

${ }^{2}$ R. S. 1840, Ch. 59, Sec. I, p. 310. 
${ }^{23}$ R. S. I86\%, Ch. 17, Sec. 5 .

"Arkansas: Sandels \& Hill, Digest of Statutes 1894, p. 352, Ch. 29, Sec. 7oo. Vermont: G. L. 1862 , Ch. 64 , Sec. I, p. 446 ; V. S. 1894, Ch. 105, Sec. 220I, p. 426. Colorado: R. S. I877, Ch. I8, Sec. 6; Mill's Ann. Stats., Vol. I, p. 584 , Sec. 432 (I89I).

${ }^{25}$ Frazer v. Board of Supervisors, 74 Ill. 282, 290; Atherton v. Roche, I92 IIl. 252, 257 (semble); Dinwiddie v. Self, I45 IIl. 290, 300 (semble).

${ }^{10}$ John de Mandeville's Case, Co. Lit. 26 b; 4 Gray's Cases on Prop., 9. ${ }^{17}$ Gray on Rule against Perpetuities, par. I08.

${ }^{18}$ Fearne C. R. 9; Fearne C. S. Smith's Notes, par 383-385; Leake, Digest of Land Laws, p. 324; Challis, Real Property (2nd ed.), p. I20. All these writers state the typical case of a contingent remainder of Fearne's fourth class to be to $A$ for life, remainder to the right heirs of J. S., who are at that time living. Challis says: " $* * *$ the remainder cannot vest until the ascertainment, or coming into being, of a person to satisfy the description in the limitation; and in the case of limitations to the heirs of a living person, such ascertainment can only take place upon his death; because nemo est heres viventis. It might at first sight be thought that the remainder is vested in the heir presumptive or heir apparent; but as the heir is, by the terms of the limitation, to take as a purchaser, and as the purchaser is to be the person who in fact comes within the description of heir, it is clear that the remainder cannot vest in the heir presumptive or apparent so long as his heirship remains only presumptive or apparent, because such a person may not, in fact, ever be the true heir at all, and therefore may never be qualified, under the terms of the limitation, to take the estate at all."

Observe that the English writers had no occasion to deal with the case of a limitation to $A$ for life with a remainder to the heirs of A's body because such a limitation would have been subject to the Rule in Shelley's Case.

${ }^{10}$ Boatman v. Boatman, 198 IIl. 4I4; Chapin v. Nott, 203 III. 341.

${ }^{20}$ Gray on Rule against Perpetuities, par. 106, 10\%.

${ }^{21}$ II5 Fed. Rep. 468.

${ }^{22}$ I64 Mo. 336. Observe, however, that in Rozier v. Graham, I46 Mo. 352, and Utter v. Sidman, I7o Mo. 284, 304, the Court was non-committal upon whether the remainder was vested or contingent.

${ }^{23} 68$ IIl. $594,598$.

${ }^{2} 68$ III. 588.

${ }^{25}$ I22 III. 317,33 I.

${ }^{26}$ I66 III. 80.

${ }^{21}$ I82 III. I7I, 177. There the Court, after stating that upon the birth of Eugene, tre first child of the donee in tail. he took an estate in fee simple subject to the donee's life estate, and subject to open and let in after born children, proceeded as follows: "When the child Eugene died before the birth of another child, such fee so vested in him passed to his heirs-at-law, who were his father and mother, subject to be divested pro tanto to let in after born children."

${ }^{28}$ Butler v. Huestis, 68 Ill. 594, 599, 600; Voris v. Sloan, 68 Ill. 588, 590; Griswold v, Hicks, 132 IIl. 494, 500.

${ }^{20}$ Welsch v. Welsch, 183.Ill. 237 ; Lancaster v. Lancaster, 187 Ill. 540.

${ }^{20}$ Such is the reasoning of Mr. Justice Shope in Lehndorf $v$. Cope, 122 
IIl. 3I7, 33I. There the deed ran to "M. A. L. and her heirs by her present husband, H. L." This was held to give M. A. L. a fee tail special at common law which the statute on estates tail turned into a life estate to M. A. L. and a remainder in fee to the bodiiy heirs of herself and her rusband. The Court then said that even proceeding upon the supposition that M. A. L. took a life estate by the original limitation in the deed the result would be the same, since M. A. L. by the Rule in Shelley's case "would, at common law, be seized of an estate in fee tail, and brought directly within the terms of Section 6 of the Conveyance Act.

II A. \& D. R. E. S. 439; Laws r819, p. 223 (I A. \& D. R. E. S. 446); Laws 1829, p. IgI (I A. \& D. R. E. S., p. 464); R. S. 1845, Ch. I09, Sec. 46 (I A. \& D. R. E. S. 505); Laws I87I-2, p. 352, Sec. I (I A. \& D. R. E. S. 579) : R. S. I874, Ch. 39, par. I (Hurd's R. S. I901, p. 677).

sI55 Fed. Rep. 468 (C. C. A.).

${ }^{3} \mathrm{r} 64$ Mo. 336 .

${ }^{34} \mathrm{I} 46 \mathrm{Mo} .352$.

ss Horseley v. Hilburn, 44 Ark. 458; Myar v. Snow, 49 Ark. 125; Wilmans 2. Robinson, 67 Ark. 517.

${ }^{3}$ Viris v. Sloan, 68 III. 588; Lehndorf v. Cope, 122 Ill. 317, 330 (semble); Kyner v. Boll, I82 Ill. I7I, I77 (semble); Turner v. Hause, 199 Ill. 464, 47I (semble).

"Thompson v. Carl, 5I Vt. 408.

${ }_{2}$ Bl., Com., Ch. 14, pp. 200-240; 4 Gray's Cases on Property, 9.

${ }^{\star 2}$ Frame v. Humphreys, I64 Mo. 336; Burris v. Page, I2 Mo. 358.

${ }^{\infty}$ This reasoning evidently prevailed over a strong prejudice against the result which it entailed, for in Rozier v. Graham, $146 \mathrm{Mo}$. 352, at page 360 , the Court had said: "It might prove interesting to examine and discuss at length the exceedingly ingenious and plausible argument of the able counsel for Mirs. Mullen trat our statute of 1835 [Mo. R. S. I835, Act of Conveyances, Sec. 5] decking entails has been the means of preserving the common law rule of descent of primogeniture, but having disposed of the only two grounds upon which his contention could possibly exist in this case, the stress of work forbids that we should enter upon such a discussion. While it is somewhat startling, we do not think it is altogether new, and we feel justified in saying that however plausible the theory evolved from the mere words of the statute, no such construction ever has been given that statute in this State, or ever will be. There are no mourners for the doctrine of primogeniture in this State."

"I A. \& D. R. E. S., 439; also L. 1819, p. 223 (I A. \& D. R. E. S. 446).

"Corbin v. Healy, 20 Pick. (Mass.) 514 (1838); Wight v. Thayer, 67 Mass. 284 (1854).

${ }^{4}$ Reinhart v. Lantz, $37 \mathrm{~Pa}$. St. 488 ( 1860 ), overruling the earlier case of Price v. Taylor, 4 Casey (Pa.) 95, 106, $28 \mathrm{~Pa}$. State 95, 106.

Sauder v. Morningstar, I Yeates (Pa.) $3^{\mathrm{I}} 3$, is no authority upon the point of the text because there the statute of descent (Act of I705) only regulated the descent of lands amongst children, where the father is seized thereof, and might dispose of them by deed or will.

"Riggs v. Sally, I5 Me. 408 (1839).

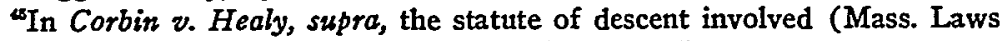
of 1780-179r, p. 124, Act of March 9, 1784) read: "That when any person 
shall die seized of lands, tenements or hereditaments, not by him devised, the same shall descend in equal shares to and among his children," etc.

In Reinhart v. Lantz, supra, the statute involved (Session Laws of Pa., 1832-3, p. 315) applied to "the real and personal estate of a decedent, whether male or female, remaining after payment of all just debts and legal charges, which shall not have been sold or disposed of by will or limited by marriage settlement."

${ }^{10}$ In I Leading Cases in American Law of Real Property (note by Sharswood and Budd), I04.

"77"The existence and incidents of an estate tail, have always been recognized in this Commonwealth, and provision made for an easy mode of barring them; and common recoveries to bar them have been in frequent use." Per Shaw, C. J., in Corbin v. Healy, 20 Pick. (Mass.) 514, 517 (1838). In Sauder v Morningstar. I Yeates 313 (1793), counsel who were arguing that the estate tail descended to all the sons equally were stopped by the Court. "The Court observed that it was too late now to stir this point whatever reason there might have been for it in the first instance. The invariable opinion of lawyers since the Act of 1705 has been, that lands entailed descended according to the course of the common law. and it has been understood generally, that it has been so adjudged in early times. All the common recoveries which have been suffered by the heirs of donees in tail have been conformable to that principle; to unsettle so many titles at this late day would be productive of endless confusion."

${ }^{48}$ See language of the Court in Price v. Taylor, $28 \mathrm{~Pa}$. Stat. 95 at 106; 4 Casey 95, ro6.

"See the suggestion of Lowrie, J., in Price v. Taylor, 28 Pa. St. 95, I06; 4 Casey 95 , Io6.

${ }^{80}$ It might be urged that the Act of 1827 itself furnishes an example where a reference to the common law admittedly includes a statutory amendment of the common law, since, while referring to "cases where by the common lawe any person or persons might hereafter become seized, in fee tail," cases where by the statute de donis of Edward I any person is seized in fee tail are meant. But a fair argument can hardly be drawn from this because the result was reached not because "common law" includes a subsequent statutory amendment of the common law, but because the statute in terms applied to estates tail and at common law there were none such at all.

${ }^{51}$ The Court adds that by the Revision of 1845 "this last vestige of the system of feudal tenures was swept from our statute book." That is true because the Act of 1845 referred to must have been Mo. R. S. I845, p. II6, Sec. 5 (Act regulating conveyances), where it was provided that the remainder "shall go and be vested in the children of such grantee or devisee equally to be divided among them," etc. But by the Act of 1866 (see supra note 6), this "last vestige of the system of feudal tenures" was evidently restored by the re-enactment of the Act of 1825 regarding entails. (Frame v. Humphreys, I64 Mo. 336.)

"Laws I829, p. I9I ; r A. \& D. R. E. S., p. 464 , Sec. 46.

${ }^{23}$ R. S. 1845 , p. 534 , Sec. 46.

R. S. 1874 , p. 417 , Ch. 39 , Sec. I.

${ }^{5}$ Cooper v. Cooper, 76 Ill. 57 ; Welliver v. Jones, I66 I1l. 80.

${ }^{60}$ Cooper v. Cooper, supra. 
"Welliver v. Jones, supra.

${ }^{*}$ Rev., p. 299, Secs. Io and II.

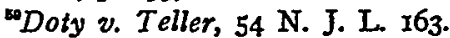

${ }^{\infty}$ Zabriskie v. Wood, 23 N. J. Eq. 54I; Weart v. Cruser, 49 N. J. L. 475 , 480.

"I Hayes' Conveyancing, 543 .

"In the following cases the Court said that the Rule had no application in case of an estate tail: Baker v. Scott, 62 Ill. 86, 98; Griswold v. Hicks, I32 Ill. 494, 501; Schaefer $v$. Schaefer, I4I Ill. 337, 343. In the following cases the same thing was assumed without mention of the point: Blair $v$. Van Blarcum, 71 I11. 290; Welliver v. Jones, I66 I1l. 80; Atherton v. Roche, 192 IIl. 252.

"It was also destructable. How far it may still be destructable by means other than the creation of the preceding statutory estates is not here considered.

"Gray, Rule against Perpetuities, par. Io8.

203 Ill. 34I.

"This position was squarely taken by the Court, but it was unnecessary to the result reached. The only object in calling the remainder vested was so that it might pass by descent upon the death of the remainder-man. It would just as clearly have descended if it had been a contingent remainder, since the death of the remainder-man was not an event which forever made it impossible for the remainder to vest. (Fearne C. R. 364; Gray, Rule against Perpetuities, par. II8.) It seems, however, that the position of the Court that the remainder was vested was supported by the case of Boatman v. Boatman, 198 Ill. 414 .

"Gray, Rule against Perpetuities, pars. I06-107.

${ }^{\circ}$ Evers v. Challis, 18 Q. B. 224, 23I; 7 H. L. C. 53I; Gray, Rule against Perpetuities, pars. 338-340a. No separation of contingencies can be accomplished upon the reasoning if the ultimate interest is an equitable interest in realty. In re Bence, Smith v. Bence (I89I), 3 Ch. 242.

"This is founded upon the rule that a future interest must take effect as a contingent remainder rather than as an executory springing or shifting future interest. (2 Preston, Abs., 153-154.) It is supported by every case where a contingent remainder has been held to be destroyed because of the failure of the event to happen upon which the remainder would vest before the termination of the preceding estate.

${ }^{70} 159$ Ill. 300 . There the rule of the feudal law of remainders that a fee cannot be mounted upon a fee by way of remainder triumphed over the later rule of conveyancing under the statute of uses that by bargain and sale a fee might be mounted upon a fee by way of shifting use.

${ }^{\text {TI}}$ I59 III. 300 .

"202 III. 275.

${ }^{73}$ Forth v. Chapman, I P. Wms. 663; 5 Gray's Cases on Property, 256.

"Smith v. Kimbell, ${ }_{53}$ Ill. 368; Hinrichsen v. Hinrichsen, 172 I11. 462.

${ }^{13}$ Theobald's Law of Wills, 563 .

${ }^{76}$ I07 Tenn. 54.

$\pi_{203}$ IIl. 34I.

${ }^{78}$ The usual expression seems to have been "for default of such issue." 
2 Greenleaf's Cruise on Real Property, 666; Hayes and Jarmen, Forms of Wills (8th ed.), 388 .

${ }^{79}$ I Vic. c. 26 s. 29; Leake, Digest of Land Lar, 183; Theobald on Wills, p. $535 ; 2$ Jarmen on Wills (6th ed.), r322 (star page).

${ }^{80} 2$ Hill $554 ; 2$ Denio 336.

${ }_{2} 2$ Denio 336 .

"The language of the will in this case was particularly strong for an indefinite failure of issue. It read, to Rachel and the heirs of her body forever; "and in case of her death without such heirs," then to another.

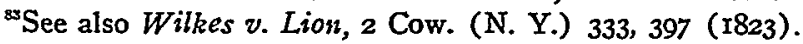

